\title{
Model Pelanggaran dalam Pelaksanaan Pemilihan Kepala Daerah Kabupaten Pelalawan Berdasarkan Undang-Undang Pemilihan Kepala Daerah Tahun 2020
}

\author{
Adrian Faridhi' ${ }^{1}$, Alexsander Yandra ${ }^{2}$ and Sudi Fahmi ${ }^{3}$ \\ 1,2,3 Universitas Lancang Kuning, Pekanbaru, Indonesia \\ adrian@unilak.ac.id
}

\begin{abstract}
Election violations in the Pelalawan Regency Head Election will be used as evaluation material in the implementation of the next general election, the findings of violations provide a model/form for improvement. This study uses a normative legal research method that uses a statutory approach. The findings of this study are a model of election violations in the form of election criminal violations, election administrative violations, ethical violations and other legal violations, this is based on findings and reports examined by Bawaslu and Gakumdu.
\end{abstract}

Keywords: Pilkada, Election Violations, Sanctions

\begin{abstract}
Abstrak
Pelanggaran pemilu pada Pilkada Pelalawan akan dijadikan bahan evaluasi dalam pelaksanaan pemilu berikutnya, temuan pelanggaran memberikan model/formulir perbaikan. Penelitian ini menggunakan metode penelitian hukum normatif yang menggunakan pendekatan perundangundangan. Temuan penelitian ini adalah model pelanggaran pemilu berupa pelanggaran pidana pemilu, pelanggaran administrasi pemilu, pelanggaran etika dan pelanggaran hukum lainnya, hal ini berdasarkan temuan dan laporan yang diperiksa oleh Bawaslu dan Gakumdu.
\end{abstract}

Kata kunci: Pilkada, Pelanggaran pemilu, sanksi

\section{Pendahuluan}

Pesta demokrasi ditingkat lokal (daerah) berupa pelaksanaan pemilihan kepala daerah yang terdiri dari pemilihan gubernur dan wakil gubernur, bupati dan wakil bupati hingga walikota dan wakil walikota. Pemilihan kepala daerah serentak (selanjutnya disebut Pilkada) pada tahun 2020 merupakan upaya untuk menciptakan local accountability, political equity dan local responsiveness (Arifulloh, 2015) yang dilaksanakan dalam suasana pandemi Covid-19.

Terbitnya Undang-Undang Republik Indonesia Nomor 6 Tahun 2020 tentang Penetapan Peraturan Pemerintah Pengganti Undang-Undang Nomor 2 Tahun 2020 tentang Perubahan Ketiga Atas UndangUndang Nomor 1 Tahun 2015 Tentang Penetapan Peraturan Pemerintah Pengganti Undang-Undang Nomor 1 Tahun 2014 tentang Pemilihan Gubernur, Bupati, dan Walikota menjadi Undang-Undang ketentuan ini menjadi dasar hukum dari pelaksanaan Pilkada Tahun 2020 dasar dari akhir polemik pelaksanaan Pilkada pada masa pandemik COVID-19.

Pelaksanaan Pilkada yang menjadi perhatian publik menyajikan janji pasangan calon (Faridhi, 2017), calon yang menampilkan citra yang baik (Perdana, 2019) kepada masyarakat untuk dipilih saat hari pencoblosan. Upaya mendapatkan dukungan pemilih ini yang memiliki potensi dari pelanggaran yang diatur dalam Undang-Undang Pilkada.

Pilkada dipersiapkan berbagai instrumen hukum dan etik menjaga kualitas dan legitimasi pasangan terpilih, namun pelanggaran yang sering ditemui dalam Pemilu maupun Pilkada berupa Polemik berkaitan DPT (Faridhi, 2018), keterlibatan Aparatur Sipil Negara (ASN) dalam pelaksanaan Pemilu maupun Pilkada (Sutrisno, 2019), praktik uang yang sulit dicegah dalam Pilkada (Chaniago, 2016), pelanggaran ini yang diantisipasi oleh 
Undang-Undang Pilkada dengan membagi jenis pelanggaran pemilu berupa:

a. Pelanggaran Etik;

b. Pelanggaran Administrasi;

c. Pelanggaran Pidana; dan

d. Sengketa hasil Umum/Pilkada.
Pemilihan
Prananingtyas, 2020). Politik Uang terjadi dipengaruhi oleh faktor ekonomi, kualitas pendidikan, lemah pengawasan (Fitriani et al., 2019), hal ini yang mempengaruhi kualitas dari pelaksanaan pesta demokrasi. Perkara-perkara money politic masih terjadi dalam pelaksanaan Pemilu 2019, namun

Sehingga pelanggaran dalam pelaksanaanbanyak dihentikan pada proses Pilkada di Kabupaten Pelalawan tahun 2020,penyeledikan disebabkan kurangnya alat oleh karena itu Peneliti ingin melakukanbukti (Solekha et al., 2020). Praktik money penelitian dengan judul "Model Pelanggaranpolitic bukannya hanya dalam bentuk uang, dalam Pelaksanaan Pemilihan Kepala Daerahnamun dapat berupa barang seperti Kabupaten Pelalawan Berdasarkan Undang-kebutuhan pokok (Yulianto, 2019).

Undang Pemilihan Kepala Daerah Tahun Pelanggaran dalam pelaksanaan 2020”.

Berkaitan dengan latar belakang di atas maka perumusan masalah dalam penelitian ini, sebagai berikut:

1. Bagaimana Model Pelanggaran Pemilihan Kepala Daerah Kabupaten Pelalawan tahun 2020?

2. Bagaimana proses penyelesain pelanggaran Pemilihan Kepala Daerah Kabupaten Pelalawan tahun 2020?

\section{Tinjuan Pustaka}

Elemen demokrasi salahsatunya berasal dari Pemilihan Umum (Bachtiar, 2014) menjadikan kedaulatan rakyat sebagai sentral kajiannya. Namun dalam pelaksanaan Pemilu ataupun Pilkada berpotensi terjadi pelanggaran, seperti dalam Penelitian yang dilakukan oleh Asbudi Dwi Saputra yang menerangkan terdapanya himbauan untuk menjaga netralitas yang dapat meningkatkan pemahaman ASN serta peningkatan pengawasan ASN (Saputra, 2020). Namun regulasi berupa sanksi dan ancaman sudah ada, tapi pelanggaran netralitas masih terjadi (Jayanti, 2019).

Pelanggaran Netralitas ASN menjadi permasalahan dalam keterlibatan birokrasi dalam politik praktis, selain itu permasalahan politik uang (money politic) maraknya money politic perlahan akan mencederai prinsip demokrasi itu sendiri, sebab kedaulatan rakyat dinilai dengan uang (Nabila, Nisa, Paramita peraga yang tidak ditertib saat minggu tenang (Faridhi, 2020). Sengketa hasil Pemilu diselesaikan di Mahkamah Konstitusi, proses ini mesti mendapat kepercayaan publik (Zuhro, 2019) untuk mendapatkan menjaga stabilitas keamanan nasional.

\section{Metode}

Penelitian merupakan kegiatan yang memiliki tujuan untuk mendapatkan, mengembangkan serta menguji kebenaran, sebab kebenaranlah yang bisa "memuaskan" keinginan tahu manusia (Barus, 2013), Jenis penelitian ini adalah penelitian hukum normatif yang dilakukan dengan cara meneliti bahan pustaka atau data sekunder berkaitan dengan objek penelitian tentang model pelanggaran pemilihan bupati dan wakil bupati Kabupaten Pelalawan tahun 2020.

Sebagai sumber data dalam penelitian ini adalah: Data sekunder adalah data yang diperoleh dari buku-buku literatur yang mendukung dengan pokok permasalahan yang dibahas. Data sekunder dapat berupa skripsi, tesis, disertasi, jurnal, surat kabar, makalah, seminar, brosur, dan lainnya. Dan Data tertier, yaitu data yang diperoleh melalui kamus, ensiklopedia, makalah, dan sejenisnya yang berfunsi mendukung data primer dan sekunder.

Untuk memperoleh data yang rerlevan guna menjawab persoalan-persoalan yang ada, pengumpulan dalam penelitian ini kampanye juga terjadi berupa terdapat alat 
menggunakan alat sebagai berupa kajian pustaka, yaitu teknik dilakukan dengan metode pengumpulan data melalui literatur kepustakaan yang memiliki korelasi dengan permasalahan yang sedang diteliti.

Dalam data penulis mengelompokkan berdasarkan persoalan yang ada, kemudian dilakukan pengolahan data. Selanjutnya data tersebut dianalisis secara kualitatif yang kemudian diungkap dalam bahasa dan kalimat secara deskriptif kualitatif, yakni memberikan penjelasan terhadap permasalahan dan penyelesaian permasalahan yang diajukan secara sistematis dan menyeluruh. Adapun teknik penyimpulan data hasil penelitian digunakan dengan metode induktif, yaitu menarik kesimpulan dari pernyataan yang bersifat khusus kedalam pernyataan yang bersifat umum.

\section{Hasil dan Pembahasan}

Pemilihan Kepala Daerah Kabupaten Pelalawan Tahun 2020 menemukan beberapa pelanggaran, dari pelanggaran pidana pemilu seperti politik uang, pelanggaran administrasi seperti persoalan netralitas ASN, pelanggaran etik seperti pelanggaran yang dilakukan Panitia Pengawas Kecamatan yang pada akhirnya diberhentikan hingga pelanggaran lainnya. Pelanggaran pemilu kepala daerah di Kabupaten Pelalawan tetap terjadi meskipun sudah diatur dalam UndangUndang Pilkada maupun peraturan turunan seperti Peraturan KPU maupun Peraturan Bawaslu. Model pelanggaran yang terjadi di Pelalawan ini memberikan gambaran bahwa tetap terjadi pelanggaran pemilu.

\subsection{Model Pelanggaran Pemilu Kepala Daerah Kabupaten Pelalawan}

Pemilihan Kepala Daerah
Kabupaten Pelalawan tahun 2020 dilaksanakan pada tanggal 09 Desember 2020 diikuti oleh empat pasangan calon Bupati dan Wakil Bupati.

Daftar Pemilih Tetap (DPT) pada pemilihan Bupati dan Wakil Bupati Pelalawan Tahun 2020 sebanyak 219,203 Pemilih dan Jumlah TPS sebanyak 850 TPS yang tersebar di 12 kecamatan yang ada di Kabupaten Pelalawan, sebagai beikut:

Tabel 2

Sebaran Daftar Pemilih Tetap (DPT) dan

Tempat Pemungutan Suara (TPS)

Pemilihan Bupati dan Wakil Bupati

Kabupaten Pelalawan Tahun 2020

\begin{tabular}{clcc}
\hline No & \multicolumn{1}{c}{ Kecamatan } & TPS & DPT \\
\hline 1 & Ukui & 90 & 24.442 \\
2 & Pangkalan Kerinci & 183 & 47.038 \\
3 & Pangkalan Kuras & 128 & 34.486 \\
4 & Pangkalan Lesung & 63 & 16.614 \\
5 & Langgam & 63 & 17.120 \\
6 & Pelalawan & 42 & 10.343 \\
7 & Kerumutan & 62 & 15.495 \\
8 & Bunut & 36 & 9.141 \\
9 & Teluk Meranti & 44 & 11.347 \\
10 & Kuala Kampar & 55 & 12.475 \\
11 & Bandar Sei Kijang & 42 & 10.470 \\
12 & Bandar Petalang & 42 & 10.232 \\
\hline \multicolumn{2}{c}{ Total } & \\
\hline Sumber: KPU Kabupaten Pelalawan &
\end{tabular}

Berdasarkan Data yang diperoleh dari Bawaslu Kabupaten Pelalawan telah melakukan proses penanganan pelanggaran terhadap enam laporan dan 16 temuan dugaan pelanggaran pemilihan kepala daerah di Kabupaten Pelalawan, berupa:

a. Pelanggaran tindak pidana pemilihan;

b. Pelanggaran kode etik penyelenggara pemilihan;

c. Pelanggaran administrasi pemilihan; dan

d. Pelanggaran peraturan perundang-undangan lainnya.

4.2 Penyelesaian Pelanggaran Pemilu Kepala Daerah Kabupaten Pelalawan 
Bupati disini untuk menengok ini, jadi besok tak kuatir lagi. Pak bupatinya setuju ya? Setuju ya? Besok pak Edi Sukemi itu Bupatinya disini untuk nengok ini setuju ya? A.... itu harapan saya. ...." pada saat menyampaikan kata sambutan pada acara peresmian kolam berenang di desa Bukit lembah Subur.

c. Berdasarkan Nomor registrasi 002/TM/P $\mathrm{B} / \mathrm{KAB} / 04.08 / \mathrm{XIII} / 2020$ atas nama Emilia KH sebagai kepala sekolah yang dijatuhi sanksi berupa sanksi sedang, sedangkan kronologis pelanggarannya berupa Dugaan Pelanggaran Kode Etik ASN yang diatur dalam Pasal 11 huruf c PP Nomor 42 Tahun 2004 dan Surat Edaran Bupati Pelalawan Nomor: 800/BKPSDM PEMKA/2020/1108 tanggal 22 Juni 2020 karena Sdri. Emilia yang bertindak sebagai Pembawa Acara/ MC dalam kegiatan silaturahmi antara Kepala Sekolah se-Kabupaten Pelalawan dengan Bupati Pelalawan dan Ketua DPRD Kabupaten Pelalawan menyampaikan Adi Sukemi sebagai calon Bupati Pelalawan dengan cara menyampaikan pantun yang berbunyi "Anak dara pergi ke langkan, sampai di langkan mencari ikan, arahan Adi Sukemi yang kita nantikan, sebagai calon Bupati Pelalawan ke depan".

d. Berdasarkan Nomor Registrasi 001/TM/P B/KEC P.KERIN CI/04.08/I X/2020 atas nama Samsidar sebagai kepala sekolah, menerima sanksi berupa sanksi moral, sedangkan kronologisnya berupa Dugaan Pelanggaran Kode Etik ASN yang diatur dalam Pasal 11 huruf c PP Nomor 42 Tahun 2004 dan Surat Edaran Bupati Pelalawan Nomor: 800/BKPSDM PEMKA/2020/1108 tanggal 22 Juni 2020 karena Saudari Samsidar. M.Pd tersebut memberikan komentar pada salah satu foto Bakal Pasangan Calon Bupati dan Wakil Bupati Pelalawan Tahun 2020 yang menggambarkan adanya pujian serta ikut mendoakan dengan isi komentar "Sangat sederhana skali Insyah Allah terujud Aamiin.

\section{Tahap Kampanye}

Pelanggaran di tahapan kampanye pada pemilihan Bupati dan Wakil Bupati Pelalawan Tahun 2020, sebagai berikut: a. Berdasarkan nomor registrasi 004/TM/PB/Kab/04.08/X/2020 atas nama Srinoralita sebagai Plt. Kepala Dinas Sosial dan Meksi Syafrida sebagai Kepala Seksi Jaminan Sosial Keluarga, dijatuhi sanksi berupa Pidana penjara masing masing selama 2 bulan dan denda sejumlah Rp 4 juta rupiah subsider 1 bulan, sedangkan kronologis peristiwa berupa Dugaan Pelanggaran Tindak Pidana Pemilihan yaitu melanggar larangan Pasal 188 Jo Pasal 71 Ayat (1) Undang-Undang Nomor 10 Tahun 2016 tentang Perubahan Kedua Atas Undang Undang Nomor 1 Tahun 2015 tentang Penetapan Peraturan Pemerintah Pengganti Undang-Undang Nomor 1 Tahun 2014 tentang Pemilihan Gubernur, Bupati, dan Walikota Menjadi Undang-Undang dengan cara merekam video investigasi adanya penyerahan bansos yang dipolitisasi oleh salah satu pasangan calon, kemudian video tersebut tersebar di masyarakat melalui media sosial.

b. Berdasarkan Nomor registrasi temuan/ aduan 005/TM/PB/Kab/04.08/X/2020 atas nama Susi Yanti sebagai Ketua Kelompok PKH dijatuhi sanksi berupa Pidana penjara 6 bulan dan denda 200 juta rupiah subsider 1 bulan kurungan dengan ketentuan pidana tersebut tidak perlu dijalankan, kecuali kemudian hari ada perintah lain dalam putusan hakim bahwa terpidana sebelum, dengan kronologis peristiwa berupa Dugaan Pelanggaran Tindak Pidana Pemilihan yaitu melanggar larangan Pasal 187A Jo Pasal 73 Ayat (4) Undang-Undang Nomor 10 Tahun 2016 Tentang Perubahan Kedua Atas Undang-Undang Nomor 1 Tahun 2015 Tentang Penetapan Peraturan Pemerintah Pengganti Undang-Undang Nomor 1 Tahun 2014 Tentang Pemilihan Gubernur, Bupati, dan Walikota Menjadi Undang-Undang dengan cara memberikan tas yang beruliskan "BangKRI, insyaallah, Zukri Bupatiku" kepada anggota kelompok PKH.

c. Berdasarkan temuan/ aduan 001/REG /LP/PB/K AB/04.08 /X/2020 atas nama Hendry Gunawan sebagai Kepala Dinas KOMINFO dan Ryan Pratama sebagai kepala seksi informasi publik dijatuhi sanksi disiplin tingkat sedang, sedangkan kronologis peristiwanya berupa Tindakan Dinas KOMINFO Kabupaten Pelalawan dan 
Aparatur Sipil Negara yang menguntungkan salah satu pasangan calon dengan cara melakukan tag name calon pada postingan media sosial resmi kominfo.

d. Berdasarkan temuan/aduan yang teregistrasi dengan nomor 001/TM/PB/KEC PLWN/04.08/X/2020 atas nama Baharuddin sebagai Kepala Sekolah dijatuhi sanksi Pidana penjara selama 4 bulan dan denda sejumlah 2 juta rupiah subsider 1 bulan kurungan, dengan kronologis peristiwa berupa Sdr. Baharuddin selaku ASN yang menjabat sebagai Kepala Sekolah SD N 06 Desa, karena terlibat ikut serta dalam kegiatan kampanye Pasangan Calon Nomor Urur 4 di Desa Sering pada hari kamis tanggal 15 Oktober 2020.

e. Berdasarkan temuan/aduan yang teregistrasi dengan nomor 001/TM/PB/KEC P.KURAS/04.08/ X/2020 atas nama Suyanto sebagai Perangkat Desa, dijatuhi sanksi berupa Peringatan lisan, Pada saat acara kampanye dialaogis akan selesai, tim sukses dan para pendukung paslon nomor urut 2 melakukan yel-yel dan mengacungkan dua jari sebagai symbol nomor urut 2 sebagai bentuk dukungan terhadap paslon nomor urut 2, pada saat itulah tertangkap kamera bahwasanya bapak suyanto yang menjabat sebagai kaur kesra di desa sialang indah sedang mengacungkan dua jari pertanda mendukung paslon nomor urut 2 pada Pilkada Pelalawan Tahun 2020.

f. Berdasarkan temuan/aduan yang teregistrasi dengan nomor

006/TM/P

$\mathrm{B} / \mathrm{KAB} / 04.08 / \mathrm{XI} / 2020$ atas nama Husni Tamrin sebagai calon bupati, T. Edy Sabli sebagai Calon wakil bupati, T. Azmun Jaafar sebagai Ketua Tim Kualisi, Waharno, Muslim, T. Rahmatsyah, Safaruddin, T.M. Salim, Mustami, Kasa dan Anuar dijatuhi sanksi berupa sanksi administratif yaitu penarikan bahan kampanye, dengan dasar berupa Penyebaran bahan kampanye berupa panci yang tidak sesuai dengan ketentuan Pasal 26 Ayat (1) huruf c PKPU Nomor 11 Tahun 2020.

g. Berdasarkan temuan/aduan yang teregistrasi dengan nomor 007/TM/PB/KAB/04.08/XI/2020 atas nama Simson Siahaan sebagai Simpatisan dijatuhi sanksi berupa Pidana penjara 2 bulan, dan denda 200 juta, subsider 2 bulan, dengan dasar Dugaan Pelanggaran Tindak Pidana
Pemilihan yaitu ditemukannya sembako dan bahan kampanye paslon nomor urut 4 di Kosan "Khanza" Jl.Pemda Kelurahan Pangkalan Kerinci Kota Kecamatan Pangkalan Kerinci Kab. Pelalawan pada hari senin tanggal 09 Nopember 2020 sekira jam $09.56 \mathrm{Wib}$.

\section{Praktik Politik Uang (Money Politic)}

Pelanggaran tindak pidana pemilihan berupa politik uang berdasarkan kapasitas penemu/pelapor, modus pelanggaran, serta hasil tindaklanjut proses penanganan pelanggaran oleh Sentra GAKKUMDU Kabupaten Pelalawan dapat diuraikan sebagai berikut:

a. Dugaan tindak pidana pemilihan berupa politik uang yang ditemukan oleh Bawaslu Kabupaten Pelalawan berdasarkan hasil pengawasan Kamal Ruzaman, SH selaku Anggota/Kordiv Penyelesaian Sengketa, dengan terlapor/pelaku adalah Ketua kelompok PKH (Program Keluarga Harapan) yang bernama Susi Yanti, adapun modus pelanggaran politik uang yang dilakukan adalah dengan memberikan tas yang ada nama, foto, dan tag line salah satu calon Bupati Pelalawan Tahun 2020 secara bersamaan dengan pemberian bantuan sosial berupa sembako kepada anggota kelompok PKH (Program Keluarga Harapan). Dari proses penanganan pelanggaran yang dilakukan oleh sentra GAKKUMDU kabupaten Pelalawan mulai dari penyelidikan, penyidikan, hingga sampai penuntutan di Pengadilan Negeri Pelalawan. Setelah melalui serangkaian proses persidangan, hakim Pengadilan Negeri Pelalawan memutuskan bahwa Susi Yanti terbukti melanggar larangan Pasal 187A Jo Pasal 73 Ayat (4) Undang-Undang Nomor 10 Tahun 2016 tentang Perubahan Kedua Atas Undang Undang Nomor 1 Tahun 2015 Tentang Penetapan Peraturan Pemerintah Pengganti Undang Undang Nomor 1 Tahun 2014 Tentang Pemilihan Gubernur, Bupati, dan Walikota Menjadi Undang Undang, dalam amar putusan Susi Yanti di Pidana penjara 6 bulan dan denda 200 juta Rupiah subsider 1 bulan kurungan dengan ketentuan pidana tersebut tidak perlu dijalankan, kecuali kemudian hari ada perintah lain dalam putusan hakim bahwa terpidana sebelum waktu 
percoban selama 1 tahun berakhir telah bersalah melakukan suatu tindak pidana.

b. Laporan dugaan pelanggaran tindak pidana pemilihan berupa politik uang yang dilaporkan oleh Warga Negara Indonesia yang ber KTP-el Kabupaten Pelalawan dengan inisial EJA dengan terlapor/pelaku adalah Adi Sukemi yang merupakan calon Bupati Pelalawan Tahun 2020. Dari laporan yang disampaikan menggambarkan modus yang dilakukan adalah dengan cara menghadiri kegiatan final lomba Qasidah dan Rebana yang diadakan oleh pengurus organisasi Ikatan Istri Partai Golkar, dalam kegiatan tersebut Adi Sukemi terlihat memberi hadia secara simbolis kepada pemang lomba. Setelah kegiatan tersebut ada beberapa akun fb yang memposting kegiatan tersebut dan dari postingan ada yang memposting foto dengan memperagakan symbol jari dan dalam kolom komentar juga ada ucapan dukungan kepada Adi Sukem agar terpilih menjadi Bupati Pelalawan Tahun 2020. Dari proses penanganan pelanggaran yang dilakukan oleh sentra GAKKUMDU kabupaten Pelalawan pada Pembahasan Kedua (SG II) diputuskan bahwa laporan tidak ditindaklanjuti dan dihentikan proses penanganan pelanggaran karena tidak memenuhi unsur dan bukti pelanggaran tindak pidana pemilihan sebagaimana diatur dalam Pasal 187A Ayat (3) Jo Pasal 69 huruf h, Pasal 187A ayat (1) Jo Pasal 73 ayat (4), Undang-Undang Nomor 6 Tahun 2020 tentang Penetapan Peraturan Pemerintah Pengganti Undang-Undang Nomor 2 Tahun 2020 tentang Perubahan Ketiga Atas Undang-Undang Nomor 1 Tahun 2015 tentang Penetapan Peraturan Pemerintah Pengganti Undang-Undang Nomor 1 Tahun 2014 Tentang Pemilihan Gubernur, Bupati, dan Walikota menjadi Undang-Undang.

c. Laporan dugaan pelanggaran tindak pidana pemilihan berupa politik uang yang dilaporkan oleh Warga Negara Indonesia yang ber KTP-el Kabupaten Pelalawan dengan inisial I dengan terlapor/pelaku adalah Adi Sukemi yang merupakan calon Bupati Pelalawan Tahun 2020. Dari laporan yang disampaikan menggambarkan modus yang dilakukan adalah dengan cara memberi hadia kepada pemenang lomba memancing secara tidak formal atau inisiatif sendiri karena lomba memancing tersebut diadakan oleh pemilik kolam dan hadiahnya juga disediakan oleh pemilik kolam berdasarkan uang pendaftaran peserta lomba memancing. Dari proses penanganan pelanggaran yang dilakukan oleh sentra GAKKUMDU kabupaten Pelalawan pada Pembahasan Kedua (SG II) diputuskan bahwa laporan tidak ditindaklanjuti dan dihentikan proses penanganan pelanggaran karena tidak memenuhi alat bukti Tindak Pidana Pemilihan sebagaimana diatur dalam Pasal 187 A Jo Pasal 73 Ayat (4) UndangUndang Nomor 6 Tahun 2020 tentang Penetapan Peraturan Pemerintah Pengganti UndangUndang Nomor 2 Tahun 2020 tentang Perubahan Ketiga Atas Undang-Undang Nomor 1 Tahun 2015 tentang Penetapan Peraturan Pemerintah Pengganti UndangUndang Nomor 1 Tahun 2014 Tentang Pemilihan Gubernur, Bupati, dan Walikota menjadi Undang-Undang serta tidak memenuhi unsur pelanggaran Administrasi Pemilihan karena melakukan larangan Kampanye yaitu kegiatan lain berupa perlombaan.

d. Laporan dugaan pelanggaran tindak pidana pemilihan berupa politik uang yang dilaporkan oleh Warga Negara Indonesia yang ber KTP-el Kabupaten Pelalawan dengan inisial EJA dengan terlapor/pelaku adalah Adi Sukemi yang merupakan calon Bupati Pelalawan Tahun 2020 dan Nasaruddin selaku juru kampanye pasangan calon. Dari laporan yang disampaikan menggambarkan modus yang dilakukan adalah dengan cara memberi uang kepada pemilik rumah tempat kampanye dilakukan yang selanjutnya pemilik rumah memberikan uang tersebut kepada peserta kampanye yang mengisi absensi dengan masing-masing mendapatkan uang dalam pecahan Rp. 50.000,-/peserta kampanye. Dari proses penanganan pelanggaran yang dilakukan oleh sentra GAKKUMDU kabupaten Pelalawan pada Pembahasan Kedua (SG II) diputuskan bahwa laporan tidak ditindaklanjuti dan dihentikan proses penanganan pelanggaran karena tidak memenuhi alat bukti Tindak Pidana Pemilihan sebagaimana diatur dalam Pasal 187 A Jo Pasal 73 Ayat (4) Undang-Undang 
Nomor 6 Tahun 2020 tentang Penetapan Peraturan Pemerintah Pengganti UndangUndang Nomor 2 Tahun 2020 tentang Perubahan Ketiga Atas UndangUndang Nomor 1 Tahun 2015 tentang Penetapan Peraturan Pemerintah Pengganti Undang-Undang Nomor 1 Tahun 2014 Tentang Pemilihan Gubernur, Bupati, dan Walikota menjadi Undang Undang.

e. Dugaan tindak pidana pemilihan berupa politik uang yang ditemukan oleh Bawaslu Kabupaten Pelalawan berdasarkan hasil pengawasan Kamal Ruzaman, SH selaku Anggota/Kordiv Penyelesaian Sengketa, dengan terlapor/pelaku adalah Warga Negara Indonesia yang bernama Simson Siahaan, adapun modus pelanggaran politik uang yang dilakukan adalah dengan cara menjadi tim survey pasangan calon Bupati dan Wakil Bupati Pelalawan Tahun 2020 ditingkat Kabupaten, dan Simson Siahaan juga meminta sembako kepada orang kepercayaan salah satu pasangan calon bupati pelalawan tahun 2020 yang selanjutnya sembako tersebut disimpan ditempat tinggalnya. Dalam kegiatan survey yang dilakukan oleh Simson Siahaan disertai dengan pemberian sembako tersebut kepada masyarakat yang juga sebagai koordinator tim survey ditingkat kecamatan sampai dengan tingkat desa. Dari proses penanganan pelanggaran yang dilakukan oleh sentra GAKKUMDU kabupaten Pelalawan mulai dari penyelidikan, penyidikan, hingga sampai penuntutan di Pengadilan Negeri Pelalawan. Setelah melalui serangkaian proses persidangan, hakim pengadilan negeri pelalawan memutuskan bahwa Simson Siahaan terbukti melanggar larangan Pasal 187A Jo Pasal 73 Ayat (4) Undang-Undang Nomor 10 Tahun 2016 Tentang Perubahan Kedua Atas Undang Undang Nomor 1 Tahun 2015 Tentang Penetapan Peraturan Pemerintah Pengganti Undang Undang Nomor 1 Tahun 2014 Tentang Pemilihan Gubernur, Bupati, dan Walikota Menjadi Undang-Undang Jo Pasal 53 Ayat (1) KUHP Undang-undang Republik Indonesia nomor 8 Tahun 1981 tentang Kitab Undang undang Hukum Acara Pidana dan Peraturan Mahkama Agung Repiblik Indonesia Nomor 1 Tahun 2018 Tentang Tata cara Penyelesaian Tindak Pidana Pemilihan Umum Serta Peraturan
Perundang-undangan lainnya, dalam amar putusan menyatakan Simson Siahaan telah terbukti secara sah dan meyakinkan bersalah melakukan tindak pidana "melakukan percobaan perbuatan melawan hukum memberikan materi lainnya sebagai imbalan kepada warga negra Indonesia, secara tidak langsung untuk mempengaruhi pemilih agar memilih calon tertentu" dan menjatuhkan Pidana penjara selama 24 (duapuluh empat) bulan dan denda sebesar Rp. 200.000.000,- (dua ratus juta rupiah) dengan ketentuan apabila denda tersebut tidak dibayar diganti dengan pidana kurungan selama 2 (dua) bulan.

f. Dugaan tindak pidana pemilihan berupa politik uang yang ditemukan oleh Bawaslu Kabupaten Pelalawan berdasarkan hasil pengawasan Bustami selaku Anggota/Kordiv Pengawasn, dengan terlapor/pelaku adalah Warga Negara Indonesia yang bernama Wira, adapun modus pelanggaran politik uang yang dilakukan adalah dengan cara memberikan sembako kepada tim survey salah satu pasangan calon bupati pelalawan tahun 2020. Dari proses penanganan pelanggaran yang dilakukan oleh sentra GAKKUMDU Kabupaten Pelalawan pada Pembahasan Kedua (SG II) diputuskan bahwa laporan tidak ditindaklanjuti dan dihentikan proses penanganan pelanggaran karena Tidak memenuhi 2 (Dua) alat bukti melakukan Pelanggaran Tindak Pidana Pemilihan sebagaimana diatur dalam Pasal 187A Ayat (1) Jo Pasal 73 Ayat (4) Undang-Undang Nomor 6 Tahun 2020 tentang Penetapan Peraturan Pemerintah Pengganti UndangUndang Nomor 2 Tahun 2020 tentang Perubahan Ketiga Atas Undang-Undang Nomor 1 Tahun 2015 tentang Penetapan Peraturan Pemerintah Pengganti UndangUndang Nomor 1 Tahun 2014 Tentang Pemilihan Gubernur, Bupati, dan Walikota menjadi Undang-Undang.

6. Pelanggaran Protokol Kesehatan

Corona Virus Desease 2019 yang selanjutnya disebut COVID 19 adalah penyakit yang menular yang disebabkan oleh (SARSCov-2) yang telah ditetapkan sebagai kedaruratan kesehatan masyarakat berdasarkan Keputusan Presiden Nomor 11 tahun 2020 tentang penetapan kedaruratan kesehatan masyarakat Corona Virus Desease 2019 (Covid 
19) dan sebagai bencana non alam nasional berdasarkan keputusan presiden nomor 12 tahun 2020 tentang penetapan bencana Nonalam penyebaran Virus Desease 2019 (Covid-19) sebagai bencana nasional Pengawasan tahapan dan penanganan pelanggaran pada penyelenggaraan pemilihan serentak lanjutan dilaksanakan oleh Bawaslu provinsi, Bawaslu Kabupaten/Kota, Panwaslu Kecamatan, Panwaslu Kelurahan/Desa, dan Pengawas TPS secara Hierarkis dan sesuai kewenangan dimasing-masing tingkatan pengawasan pemilihan berdasarkan ketentuan peraturan perundang-undangan.

$\begin{array}{llr}\text { Aspek } & \begin{array}{l}\text { Kesehatan dan } \\ \text { pencegahan }\end{array} & \begin{array}{r}\text { Keselamatan } \\ \text { COVID-19 }\end{array}\end{array}$
Meliputi sebagai berikut:

a. Penerapan Prinsip Keselamatan dan Kesehatan Kerja;

b. Pelaksanaan Rapid Test dan pemeriksaan kesehatan terhadap jajaran Bawaslu, Bawaslu Provinsi, Bawaslu Kabupaten/Kota, Panwaslu Kecamatan, Panwaslu Kelurahan/Desa dan Pengawas TPS sebelum atau sesudah melakukan semua tahapan Pengawasan;

c. Pemakaian alat pelindung diri Penyediaan sarana sanitasi yang memadai pada tempat dan/atau perlengkapan berupa:

1) Fasilitas cuci tangan pakai sabun dengan air yang mengalir;

2) Cairan disinfektan dan/atau antiseptic berbasis alcohol;

d. Pengecekan suhu tubuh seluruh pihak yang terlibat dengan ketentuan suhu tubuh paling tinggi 37,3 (tiga puluh tujuh koma tiga derajat) celcius;

e. Pengaturan Menjaga jarak aman paling kurang 1 (satu) Meter;

f. Pembatasan jumlah peserta dan/atau personel yang ditugaskan pada setiap kegiatan pengawasan, penanganan pada setiap kegiatan pengawasan, penanganan pelanggaran, dan penyelesaian sengketa yang mengharuskan adanya kehadiran fisik.

Menerapkan prilaku hidup bersih dan sehat. Pelaksanaan pemilihan Bupati dan Wakil Bupati Pelalawan tahun 2020 di Kabupaten Pelalawan pada tahapan kampanye ditemukan dugaan pelanggaran protokol kesehatan sebanyak 2 (dua) pelanggaran.
Pelanggaran protokol kesehatan terjadi di Kecamatan Pangkalan Kerinci berdasarkan hasil pengawasan Panwaslu Kecamatan Pangkalan Kerinci pada saat melakukan tugas pengwasan kampanye Paslon Nomor Urut $2 \mathrm{H}$. Zukri - H. Nasarudin dengan Nomor STTP Kampanye 458/X/2020 SAT INTELKAM pada Hari Selasa, 27 Oktober 2020 di Kediaman sdr. Mardianis Jl. Muhajirin Kel. Pkl. Kerinci Timur Pukul. 14.30 s.d selesai. Pada saat Pelaksanaan Kampanye Pengawas Menemukan peserta kampanye tidak menerapkan protokol kesehatan berupa masker dan tidak menjaga jarak. Selanjutnya pengawas berkoordinasi dengan aparat keamanan (Polisi dan TNI) yang berada di lokasi kampanye agar diberikan peringatan tertulis terkait protokol kesehatan, setelah berkoordinasi dan tidak ada tanda tanda akan menerapkan protokol kesehatan (Masker dan Menjaga Jarak), maka Sekitar Pukul 15.55 Wib Panwaslu Kecamatan Pangkalan Kerinci memberikan Surat Peringatan Tertulis dengan Nomor Surat nomor : 255/K.RI06.P.Kerinci/TU.00.01/X/2020 Tanggal 27 Oktober 2020 Kepada Tim Kampanye Paslon Urut 2 H. Zukri-H. Nasarudin. Selanjutnya kampanye bubar karena tim kampanye bersama pasangan calon membubarkan diri karena merasa kampanye dilokasi tersebut sudah cukum, peserta kampanye juga ikut membubarkan diri secara tertib.

Pelanggaran protokol kesehatan di Kecamatan Teluk Meranti berdasarkan hasil pengawasan Panwaslu Kecamatan Teluk Meranti Kerinci pada saat melakukan tugas pengwasan kampanye Paslon Nomor Urut $2 \mathrm{H}$. Zukri - H. Nasarudin dengan Nomor STTP Kampanye 638/X/2020 SAT INTELKAM pada Hari Rabu, 04 November 2020 di Kediaman sdr. Jainadi alamat RT.016 RW.005 Kelurahan Teluk Meranti Pukul. 19.30 Wib s.d 21.00 Wib. Pada saat Pelaksanaan Kampanye Pengawas Menemukan peserta kampanye melanggar protokol kesehatan berupa jumlah peserta kampanye melebih dari 50 orang dan tidak menjaga jarak. Selanjutnya pengawas memberikan Surat Peringatan Tertulis dengan Nomor Surat : $\quad$ 001/K.RI-06.T. Meranti/TU.00.01/X/2020 Tanggal 04 November 2020 Kepada Tim Kampanye Paslon Urut 2 H. Zukri - H. Nasarudin, dan Tim Kampanye langsung mengurangi jumlah peserta kampanye dan menjaga jarak. 


\section{Daftar Pustaka}

Arifulloh, A. (2015). Pelaksanaan pilkada serentak yang demokratis, damai dan bermartabat. Pembaharuan Hukum, II(2), 301-311.

Bachtiar, F. R. (2014). Pemilu Indonesia: Kiblat negara Demokrasi dari Berbagai Refresntasi. Jurnal Politik Profetik, 3(1), 1-17.

Barus, Z. (2013). Analisis filosofis tentang peta konseptual penelitian hukum normatif dan penelitian hukum sosiologis. Jurnal D, 13(2), 307-318.

Chaniago, P. S. (2016). Evaluasi Pilkada Pelaksanaan Pilkada Serentak Tahun 2015. Indonesian Political Science Review, 1(2), 196-211.

Faridhi, A. (2017). Riau Law Journal Vol. 1 No.2, November 2017. 1(2), 124-143.

Faridhi, A. (2018). Penggunaan Surat Keterangan dalam Pemilihan Kepala Daerah Kota Pekanbaru Tahun 2017. Jurnal Ilmiah Penegakan Hukum, 5(2), pp. 86-93.

Faridhi, A. (2020). The Violation of Campaign Props Installation in 2019 Election in Pekanbaru. Journal of Election and Leadership, 1(1), 29-36.

Fitriani, L. U., Karyadi, L. W., Chaniago, D. S., Caspar, G., Blau, P. M., Emerson, R., \& Kelly, H. H. (2019). Fenomena Politik Uang ( Money Politic ) Pada Pemilihan Calon Anggota Legislatif di Desa Sandik Kecamatan Batu Layar Kabupaten Lombok Barat. Resiprokal, 1(1), 5361.

Jayanti, N. P. (2019). Netralitas Peran Aparatur Sipil Negara dalam Kebijakan Publik dan Pemilihan Umum. Jurnal Analisa Kebijakan, 3(1), 101-107.

Nabila, Nisa, Paramita Prananingtyas, M. A. (2020). Pengaruh Money Politic dalam Pemilihan Anggota Legislatif terhadap Keberlangsungan Demokrasi di Indonesia. Noturius, 13(1), 138153.

Perdana, K. (2019). Efektifitas Alat Peraga
Kampanye Calon Anggota Legislatif: Studi Pendahuluan Pemasaran Politik Pada Generasi Milenial di Provinsi Lampung Indonesia. Wacana Poltik, 4(1), 44-54.

Saputra, A. D. (2020). Pencegahan dan Penindakan Pelanggaran netralitas Aparatur Sipil Negara (ASN) Oleh Bawaslu Kota Palopo Pada Pemilu 2019. Jurnal I La Galigio, 3(2), 9-17.

Solekha, R. R., Wantu, F. M., \& Tijow, L. M. (2020). Penegakan Hukum Terhadap Tindak Pidana Money Politic oleh Calon Anggota Legisltif Pada Pemiihan Umum 2019. Jurnal Legalitas, 13(1), 51-69.

Sutrisno. (2019). Prinsip Netralitas Aparatur Sipil Negara Dalam Pemilihan Kepala Daerah. Jurnal Hukum Ius Quia Iustum, 26(3), 521543.

https://doi.org/10.20885/iustum.vol26. iss $3 . \operatorname{art} 5$

Yulianto, I. (2019). Tinjauan Hukum Pembuktian Money Politic Berdasarkan Undang-Undang Nomor 7 Tahun 2017 tentang Pemilihan Umum. Jurnal Fenomena, 17(1), 1931-1946.

Zuhro, R. S. (2019). Demokrasi dan Pemilu Presiden 2019. Jurnal Penelitian Politik, 16(1), 69-81.

Arifulloh, A. (2015). Pelaksanaan pilkada serentak yang demokratis, damai dan bermartabat. Pembaharuan Hukum, II(2), 301-311.

Bachtiar, F. R. (2014). Pemilu Indonesia: Kiblat negara Demokrasi dari Berbagai Refresntasi. Jurnal Politik Profetik, $3(1), 1-17$.

Barus, Z. (2013). Analisis filosofis tentang peta konseptual penelitian hukum normatif dan penelitian hukum sosiologis. Jurnal D, 13(2), 307-318.

Chaniago, P. S. (2016). Evaluasi Pilkada Pelaksanaan Pilkada Serentak Tahun 2015. Indonesian Political Science Review, 1(2), 196-211.

Faridhi, A. (2017). Riau Law Journal Vol. 1 No.2, November 2017. 1(2), 124-143. 
Faridhi, A. (2018). Penggunaan Surat Keterangan dalam Pemilihan Kepala Daerah Kota Pekanbaru Tahun 2017. Jurnal Ilmiah Penegakan Hukum, 5(2), pp. 86-93.

Faridhi, A. (2020). The Violation of Campaign Props Installation in 2019 Election in Pekanbaru. Journal of Election and Leadership, 1(1), 29-36.

Fitriani, L. U., Karyadi, L. W., Chaniago, D. S., Caspar, G., Blau, P. M., Emerson, R., \& Kelly, H. H. (2019). Fenomena Politik Uang ( Money Politic ) Pada Pemilihan Calon Anggota Legislatif di Desa Sandik Kecamatan Batu Layar Kabupaten Lombok Barat. Resiprokal, 1(1), 5361.

Jayanti, N. P. (2019). Netralitas Peran Aparatur Sipil Negara dalam Kebijakan Publik dan Pemilihan Umum. Jurnal Analisa Kebijakan, 3(1), 101-107.

Nabila, Nisa, Paramita Prananingtyas, M. A. (2020). Pengaruh Money Politic dalam Pemilihan Anggota Legislatif terhadap Keberlangsungan Demokrasi di Indonesia. Noturius, 13(1), 138153.

Perdana, K. (2019). Efektifitas Alat Peraga Kampanye Calon Anggota Legislatif: Studi Pendahuluan Pemasaran Politik Pada Generasi Milenial di Provinsi Lampung Indonesia. Wacana Poltik, 4(1), 44-54.

Saputra, A. D. (2020). Pencegahan dan Penindakan Pelanggaran netralitas Aparatur Sipil Negara (ASN) Oleh Bawaslu Kota Palopo Pada Pemilu 2019. Jurnal I La Galigio, 3(2), 9-17.

Solekha, R. R., Wantu, F. M., \& Tijow, L.
M. (2020). Penegakan Hukum Terhadap Tindak Pidana Money Politic oleh Calon Anggota Legisltif Pada Pemiihan Umum 2019. Jurnal Legalitas, 13(1), 51-69.

Sutrisno. (2019). Prinsip Netralitas Aparatur Sipil Negara Dalam Pemilihan Kepala Daerah. Jurnal Hukum Ius Quia Iustum, 26(3), 521543.

https://doi.org/10.20885/iustum.vol26. iss $3 . \operatorname{art} 5$

Yulianto, I. (2019). Tinjauan Hukum Pembuktian Money Politic Berdasarkan Undang-Undang Nomor 7 Tahun 2017 tentang Pemilihan Umum. Jurnal Fenomena, 17(1), 1931-1946.

Zuhro, R. S. (2019). Demokrasi dan Pemilu Presiden 2019. Jurnal Penelitian Politik, 16(1), 69-81. 